\title{
Measurement of the CD3 4 Variant T Cell Frequency by Flow Cytometry after X-Irradiation on Mice
}

\author{
Naoki Kunugita, Nan Mei, Satoshi Nomoto and Toshiyuki Norimura \\ Department of Radiation Biology and Health, School of Medicine, University of Occupational \\ and Environmental Health, Japan
}

\begin{abstract}
Measurement of the $\mathrm{CD3}^{-} 4^{+}$Variant T Cell Frequency by Flow Cytometry after $X$ Irradiation on Mice: Naoki Kunugita, et al. Department of Radiation Biology and Health, School of Medicine, University of Occupational and Environmental Health, Japan-Variant cell frequency of mice T-lymphocytes defective in the T-cell receptor (TCR) gene expression was measured by flow cytometry. Splenic T-lymphocytes were obtained from mice after irradiation and stained with fluorescein-labeled anti-L 3 T 4 (CD 4) and phycoerythrinlabeled anti-CD3- $\varepsilon$ antibodies. They were analyzed with a flow cytometer to detect variant $T$ cells lacking surface expression of TCR/CD 3 complexes which showed $\mathrm{CD}^{-} 4^{+} \mathrm{T}$ cells. Variant $T$ cells could be observed 3 days after $3 \mathrm{~Gy}$ irradiation. Frequency of variant $T$ cells increased to the maximum level of $94 \times 10^{-4}$ between 15 and 21 days after $3 \mathrm{~Gy}$ irradiation on $B A L B / c$ mice and gradually decreased with a half-life of approximately 17 days. We examined the strain difference in radiosensitivity of splenic T-lymphocytes in BALB/C, C57BL/6, C3H/ $\mathrm{He}$ and $B 6 C 3 F_{1}$ mouse strains by this assay method. We observed that BALB/C showed the most radiosensitivity. This assay method is quick and easy in comparison with other methods and is considered useful for the mutagenicity test.
\end{abstract}

(J Occup Health 1996: 38: 25-29)

Key words: Strain difference, Radiosensitivity, $\mathrm{CD}^{-} 4^{+}$variant $\mathrm{T}$ cell, T-cell receptor gene, Flow cytometry

It is well known that somatic mutations are induced by ionizing irradiation. Many investigators have reported various different mutagenicity tests which include gene mutation, chromosomal aberration and DNA damage ${ }^{1)}$, but it is difficult to detect

Received March 30, 1995; Accepted Aug 15, 1995

Correspondence to: N. Kunugita, Department of Radiation Biology and Health, School of Medicine, University of Occupational and Environmental Health, Japan, 1-1 Iseigaoka, Yahatanishi-ku, Kitakyushu 807, Japan somatic mutations quantitatively. It is very important to evaluate the effects of mutagens not only in industry but also in our living environment.

Recently, Kyoizumi et al. established the somatic mutation assay at the $\mathrm{T}$-cell receptor(TCR) gene ${ }^{2)}$. The TCR is a heterodimer consisting of $\alpha$ and $\beta$ chains and is associated with a molecular complex referred to as CD3 antigen. Peripheral CD4 lymphocytes deficient in the expression of TCR/CD3 complex on the cell surface show $\mathrm{CD}^{-} 4^{+}$due to a somatic mutation at either the TCR $\alpha$ - or $\beta$-chain genes. They showed that the mean frequency of $T$ cells with altered TCR expression was $2.5 \times 10^{--4}$ among $\mathrm{CD}^{+}$mature $\mathrm{T}$ cells in peripheral blood from healthy donors ${ }^{2)}$. They also showed that the frequency of $T$ cells with altered TCR expression significantly increased with age among normal donors $^{2)}$, increased in Thorotorast patients who had been continuously irradiated with $\alpha$ particles ${ }^{3)}$ and increased in a dose-dependent manner among radiation-exposed donors treated with ${ }^{131}$ I for thyroid disease $^{4)}$. They showed that this assay may be useful for estimating the effects of mutagens as a biological dosimeter and for identifying high-risk cancer groups ${ }^{5}$.

On the other hand, mouse strain differences in radiosensitivity have been widely observed and are considered to be determined by several factors ${ }^{6-13)}$. Till and McCulloch demonstrated the radiation sensitivity of mouse bone marrow cells in $\mathrm{C} 57 \mathrm{Bl} / \mathrm{Ha}$ and $\mathrm{C} 3 \mathrm{Hf} / \mathrm{Ha}$ strains $^{6}$. In respect to the median lethal dose for 30-day death $\left(\mathrm{LD}_{50 / 30}\right), \mathrm{BALB} / \mathrm{c}$ was the most radiosensitive ${ }^{70}$. Radiosensitivity of lymphocytes has also been observed in a variety of end points and shown to differ in diverse strains of $\operatorname{mice}^{11,12)}$.

The present investigation was undertaken to detect variant $T$ cells lacking surface expression of TCR/CD3 complexes in mouse splenocytes after irradiation and to examine the strain difference in 
radiation-induced $\mathrm{CD}^{-} 4^{+}$variant $T$ cell frequency. We found that BALB/c mice are extremely radiosensitive in this assay. Furthermore, this TCR mutation assay method using flow cytometry is very easy and useful for screening the effects of in vivo exposure to toxic and/or mutagenic agents as well as radiation.

\section{Materials and Methods}

Animals : Seven-week-old female BALB/c, C57BL/6 and $\mathrm{C} 3 \mathrm{H} / \mathrm{He}$ mice and $F_{1}$ hybrids B6C3F $F_{1}$ were purchased from Japan SLC, Inc. (Shizuoka, Japan). After arrival, the mice were kept for a week to check their body weight and for infections, and then used for the experiments. They were housed, 10 mice per cage, on wood-chip contact bedding in a $23 \pm 2{ }^{\circ} \mathrm{C}$ air-conditioned clean room and given commercial pellet chow and water ad libitum. Research was conducted according to the principles enunciated in the "Guiding Principles for the Care and Use of Animals approved by the Faculty Meeting of UOEH".

Irradiation: Mice were placed in a special plastic box and exposed to X-rays using a Toshiba EXS300-4 X-ray apparatus (Toshiba Co., Ltd., Tokyo, Japan) in an unanesthetized condition. The Xirradiation factors were $250 \mathrm{kVp}, 0.5 \mathrm{~mm} \mathrm{Cu}+0.5$ $\mathrm{mm} \mathrm{Al} \mathrm{filter,} 50 \mathrm{~cm}$ focus-surface distance and the dose rate was $0.45 \mathrm{~Gy} / \mathrm{min}$.

Flow cytometry: Mice were sacrificed 3 to 50 days after irradiation and the spleen was sampled immediately after sacrifice. The spleen cells were gently dissociated and then filtered through a stainless steel

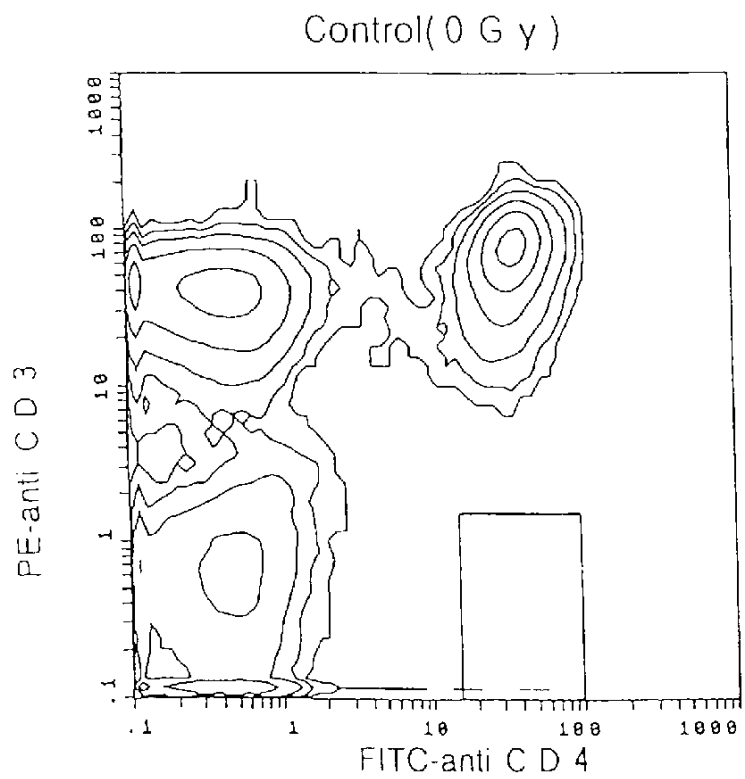

mesh. Red blood cells in the spleen cells were lysed with a Gey's solution in which $\mathrm{NaCl}$ was replaced by $\mathrm{NH}_{4} \mathrm{Cl}$. $\mathrm{T}$ cells were enriched through nylon wool columns according to Julius et al. ${ }^{14)}$. These cells, which were nylon wool non-adherent cells, contained 75 to $90 \% \mathrm{~T}$ cells.

One million cells were stained on ice for $30 \mathrm{~min}$. with fluorescein-labeled anti-L3T4 (CD4) and phycoerythrin-labeled anti-CD3- $\varepsilon$ antibodies which were obtained from PharMingen (San Diego, CA, U.S. A.). Then they were washed and analyzed with a Coulter EPICS XL flow cytometer (Coulter Corporation, Hialeah, FL, U.S. A.). Lymphocytes were examined by setting bit map gates on a plot of forward and $90^{\circ}$ light scatter, and a window for $\mathrm{CD}^{-} 4^{+}$variant $\mathrm{T}$ cells was set in the region where the surface CD3 level was $<1 / 25$ th of that for normal $\mathrm{CD}^{+}$cells according to Kyoizumi et al ${ }^{2)}$ (Fig. 1). The variant $T$ cell frequencies were calculated as the number of events in the $\mathrm{CD}^{-} 4^{+} \mathrm{T}$ cell window divided by the total number of $\mathrm{CD}^{-} \mathrm{T}$ cells.

Statistical analysis: The statistical significance in the difference between variant $T$ cell frequencies among strains was determined by one-way analysis of variance and the statistical significance between two strains was determined by the least significant difference test.

\section{Results}

Fluorescence distributions of TCR variants after $X$ irradiation: Fig. 1 shows the results of flowcytometric distributions of $\mathrm{CD}^{-} 4^{-}$variant $\mathrm{T}$ cells

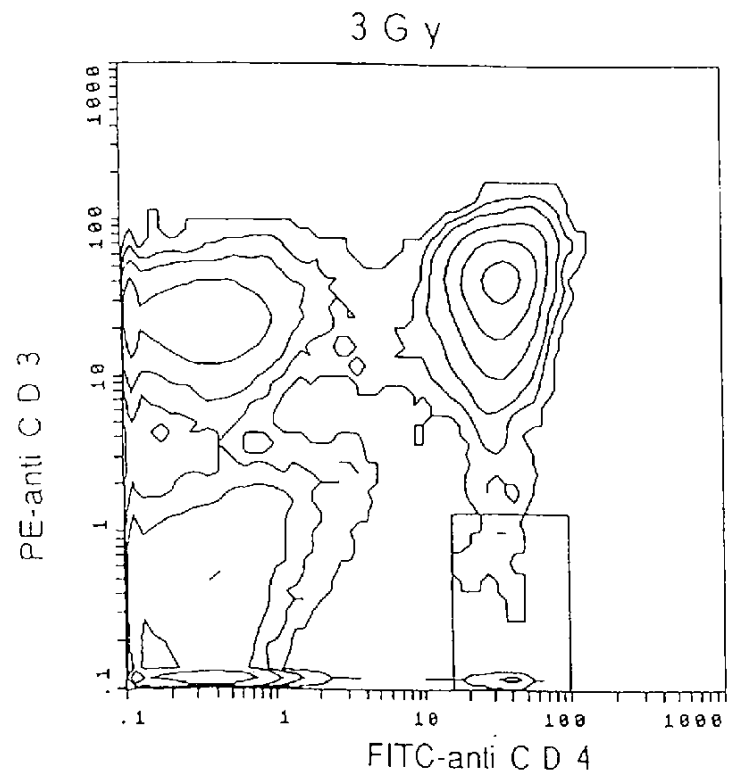

Fig. 1. Flow cytogram of splenic $T$ lymphocytes from a normal BALB/c mouse and the mouse 17 days after 3 Gy irradiation stained with fluorescein-labeled anti-L3T4 (CD4) and phycoerythrin-labeled anti-CD3- $\varepsilon$ antibodies. A window for variant $\mathrm{CD}^{-\cdots} 4^{+}$lymphocytes is shown as the square. 
from normal $\mathrm{BALB} / \mathrm{c}$ mice and the mice 17 days after 3 Gy irradiation. A window for $\mathrm{CD}^{-} 4^{+}$variant $T$ cells was set in the region shown as squares in the figure.

Determination of the length of the expression time for TCR variants: Before assaying the mutagenic effects of X-irradiation as a function of the dose, we determined the optimal length of time for the expression of TCR variants. T cells with altered TCR expression could be observed 3 days after 3 Gy irradiation. Variant $T$ cell frequency increased to the maximum levels between 15 and 21 days after $3 \mathrm{~Gy}$ irradiation and gradually declined with a half-life of almost 17 days (Fig. 2).

Strain differences in the radiosensitivity at the $T C R$ gene: Frequencies of $\mathrm{CD}^{-} 4^{+}$variant $\mathrm{T}$ cells after irradiation in each strain are shown in Fig. 3. Each mouse was sacrificed 15 to 17 days after irradiation. In all strains, $\mathrm{CD}^{-} 4^{+}$variant $\mathrm{T}$ cells were increased in a dose-dependent manner. Variant $T$ cell frequency after irradiation in $B A L B / c$

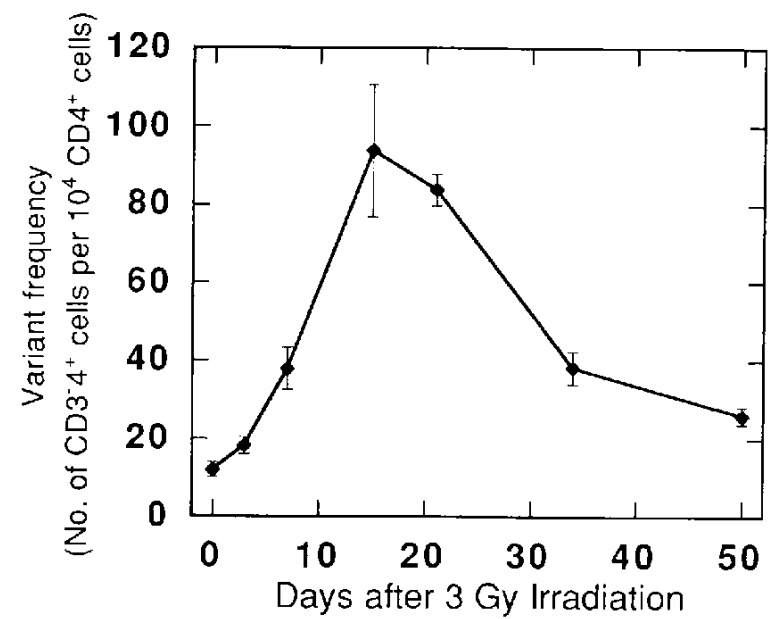

Fig. 2. Time course of variant $\mathbf{T}$ cell frequency after $3 \mathrm{~Gy}$ irradiation in BALB/c mice.

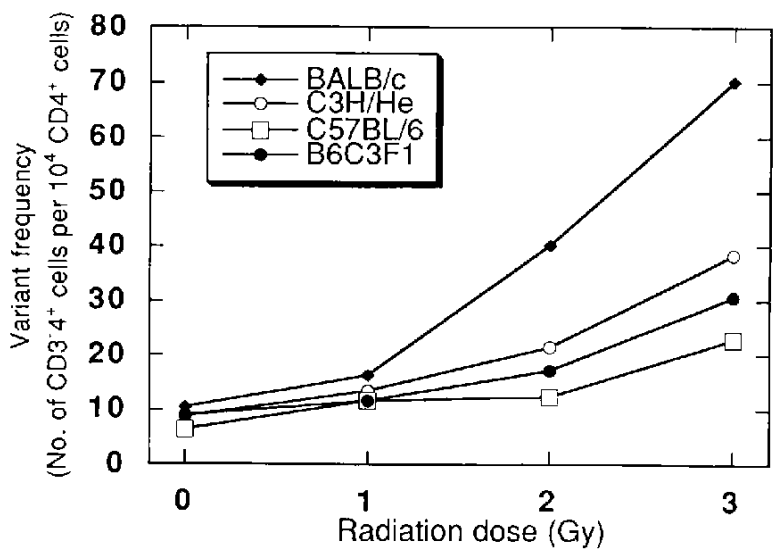

Fig. 3. Dose response curve of variant $T$ cell frequency 15 to 17 days after irradiation in $\mathrm{BALB} / \mathrm{c}, \mathrm{C} 3 \mathrm{H} / \mathrm{He}, \mathrm{B}^{2} \mathrm{C} 3 \mathrm{~F}_{1}$ and $\mathrm{C} 57 \mathrm{BL} / 6$ mice mice was significantly higher than in the other strains. Strain difference in induced $\mathrm{CD}^{-} 4^{-}$variant $\mathrm{T}$ cell frequency after $3 \mathrm{~Gy}$ is shown in Fig. 4. Induced variant $T$ cell frequencies after 3 Gy irradiation on $\mathrm{BALB} / \mathrm{c}, \mathrm{C} 3 \mathrm{H} / \mathrm{He}, \mathrm{B} 6 \mathrm{C} 3 \mathrm{~F}_{1}$ and $\mathrm{C} 57 \mathrm{BL} / 6$ mice were $59.7,29.8,21.8,16.6\left(\times 10^{4}\right)$, respectively. BALB/c mice showed the most radiosensitivity among these four strains and were induced at almost twice the variant $\mathrm{T}$ cell frequency of $\mathrm{C} 3 \mathrm{H} / \mathrm{He}$ mice. $\mathrm{C} 57 \mathrm{BL} / 6$ mice were the most resistant to $3 \mathrm{~Gy}$ irradiation.

\section{Discussion}

In this study, we have measured flow-cytometrically the variant cell frequencies of mouse $T$ lymphocytes which were defective in the TCR gene expression after whole body irradiation. Splenic Tlymphocytes were obtained from the mice after irradiation and stained with fluorescein-labeled antiL3T4 (CD4) and phycoerythrin-labeled anti-CD3- $\varepsilon$ antibodies. Variant $\mathrm{T}$ cells lacking surface expression of $\mathrm{TCR} / \mathrm{CD} 3$ complexes showed CD3 $4^{+} \mathrm{T}$ cells in a flow cytometer. They could be observed 3 days after 3 Gy irradiation. The frequency of variant $T$ cells increased to the maximum level of $94 \times$ $10^{4}$ between 15 to 21 days after $3 \mathrm{~Gy}$ irradiation on BALB/c mice and gradually decreased with a half-life of approximately 17 days. Induced variant $\mathrm{T}$ cell frequencies after irradiation on BALB/c and $\mathrm{C} 3 \mathrm{H} / \mathrm{He}$ mice were about $20 \times 10^{4}, 10 \times 10^{-4}$ per Gy, respectively. In human cases who were patients recently treated with ${ }^{131} \mathrm{I}$ for thyroid cancer, which was equivalent to a committed ${ }^{131}$ I dose of $1.05 \mathrm{~Sv}$ to the spleen, the net increased mutation frequency was $10 \times 10^{-44)}$. The data in this study

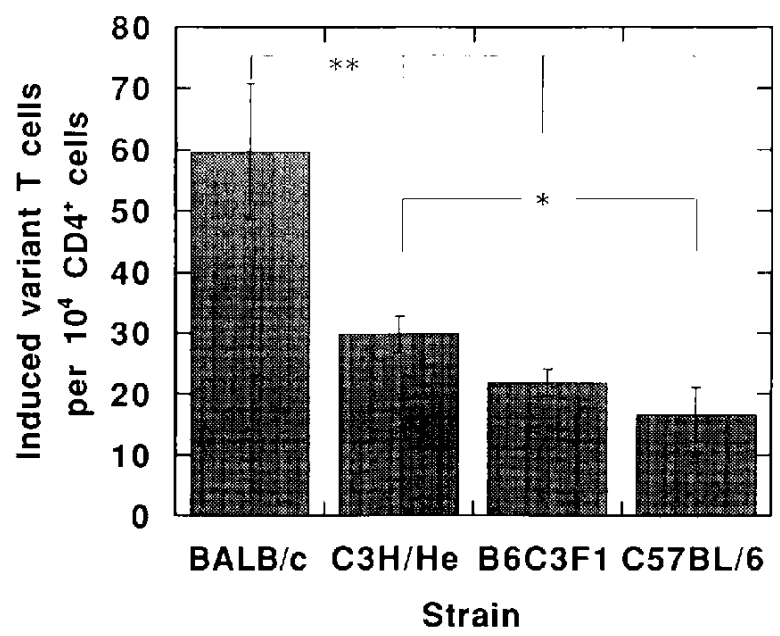

Fig. 4. Comparison of the induced frequency of variant $T$ cells by $3 \mathrm{~Gy}$ of $\mathrm{X}$-irradiation in $\mathrm{BALB} / \mathrm{c}, \mathrm{C} 3 \mathrm{H} / \mathrm{He}$, $\mathrm{B} 6 \mathrm{C} 3 \mathrm{~F}_{1}$ and $\mathrm{C} 57 \mathrm{BL} / 6$ mice ${ }^{*} ; p<0.05,{ }^{* *} ; p<0.01$. 
of mouse lymphocytes may therefore agree with the data for human lymphocytes.

Kyoizumi et al. assumed that variant CD3 $4^{-\mathrm{T}}$ cells are generated by somatic mutation of productively rearranged TCR genes in peripheral mature $\mathrm{T}$ cells ${ }^{2}$. Therefore the half-life of 17 days was probably reflected in the life span of mature $T$ lymphocytes in vivo in the mice. Another possibility is the elimination of these variant T-lymphocytes in vivo, because Kyoizumi et al. also showed that these mutant T-lymphocytes generally grow poorly in vitro ${ }^{2)}$.

Mouse strain differences in radiosensitivity were widely observed and are considered to be determined by several factors ${ }^{6-13)}$. BALB/c mice showed the most radiosensitivity and were induced at almost twice the variant $T$ cell frequency of $\mathrm{C} 3 \mathrm{H} / \mathrm{He}$ mice in this study. It has been reported that $\mathrm{BALB} / \mathrm{c}$ is one of the most radiosensitive strains shown by any assay method ${ }^{7} 10,12,13,15,16,18$ ). With respect to the median lethal dose for 30-day death $\left(\mathrm{LD}_{50 / 30}\right), \mathrm{BALB} / \mathrm{c}$ was the most radiosensitive ${ }^{710)}$. The $\mathrm{LD}_{50 / 30}$ values for $\mathrm{BALB} / \mathrm{c}$, $\mathrm{C} 3 \mathrm{Hf} / \mathrm{He}$ and $\mathrm{C} 57 \mathrm{BL} / 6$ were $500.1 \mathrm{R}, 593.2 \mathrm{R}$ and $630.3 \mathrm{R}$, respectively ${ }^{8}$. Other reports showed the same tendency in $\mathrm{LD}_{50 / 30}$ values ${ }^{7,9,10)}$. Radiosensitivity of lymphocytes has also been observed by a variety of end points and has been shown to differ among strains of mice ${ }^{11,12,15)}$. Recently, Mori et al. showed that thymocyte from $\mathrm{BALB} / \mathrm{c}$ mice is more sensitive to radiation-induced apoptosis ${ }^{15}$. They also reported that thymocytes from C57BL/6 mice showed a similar radiosensitivity to $\mathrm{BALB} / \mathrm{c}$ thymocytes, while $\mathrm{C} 3 \mathrm{H} / \mathrm{He}$ mice exhibited a resistant phenotype. We have also shown the strain difference in radiosensitivity in mice observed by colony forming assay with T-cell growth factor ${ }^{17,}{ }^{18)}$. The splenic T-lymphocyte of BALB/c was most sensitive to radiation among $B A L B / c$, $\mathrm{C} 3 \mathrm{H} / \mathrm{He}, \mathrm{C} 57 \mathrm{BL} / 6$ and $\mathrm{B} 6 \mathrm{C} 3 \mathrm{~F}_{1}$ mice $^{18)}$. For $\mathrm{BALB} / \mathrm{c}, \mathrm{C} 3 \mathrm{H} / \mathrm{He}, \mathrm{C} 57 \mathrm{BL} / 6$ and $\mathrm{B} 6 \mathrm{C} 3 \mathrm{~F}_{1}$ mice, respectively, the $\mathrm{D}_{0}$ values were $0.64 \mathrm{~Gy}, 0.97 \mathrm{~Gy}$, $0.75 \mathrm{~Gy}$ and $0.79 \mathrm{~Gy}$, while the $\mathrm{D}_{\mathrm{q}}$ values were $0.63 \mathrm{~Gy}, 0.62 \mathrm{~Gy}, 0.51 \mathrm{~Gy}$ and $0.71 \mathrm{~Gy}$. It has also been reported that $\mathrm{C} 57 \mathrm{BL} / 6$ is almost as radiosensitive a strain as BALB/c mice ${ }^{12,15)}$. Sado et al. reported that the $D_{0}$ and $D_{q}$ values in the radiosensitivity of plaque-forming cells (PFC) per spleen were $1.45 \mathrm{~Gy}$ and $0.62 \mathrm{~Gy}$ for $\mathrm{C} 3 \mathrm{H}, 0.42 \mathrm{~Gy}$ and $0.53 \mathrm{~Gy}$ for $\mathrm{BALB} / \mathrm{c}$ and $0.15 \mathrm{~Gy}$ and $0.58 \mathrm{~Gy}$ for C57BL/6 mouse, respectively ${ }^{12)}$. In this study, however, C57BL/6 was most resistant to irradiation. The reason for this discrepancy was not found and further experiments are needed to solve this problem.
On the other hand, we have observed the frequency of TCR mutants and 6-thioguanine-resistant cells determined by a cloning at the hypoxanthinguanine phosphoribosyltransferase (HPRT) gene after treatment with $250 \mathrm{kVp} \mathrm{X}$-rays or ethylnitrosourea (ENU) on human lymphocytes in vitro. There was a linear relationship between mutation induction on TCR genes and the HPRT gene after both treatments ${ }^{19)}$.

In conclusion, this assay is a very useful method to measure the variant cell frequencies not only for human lymphocytes but also for mouse lymphocytes, because it requires a small number of cells, a short period for the measurement and antibodies are commercially available.

Acknowledgments: The authors thank Ms. $\mathrm{H}$. Kakihara, Mr. K. Inokuchi and Mr. N. Minagawa for their technical assistance.

\section{References}

1) Galloway SM ed. Report of the international workshop on standardisation of genotoxicity test procedures. Mutation Res 1994 ; 312: 195-322.

2) Kyoizumi S, Akiyama M, Hirai Y, Kusunoki $Y$, Tanabe K, Umeki S. Spontaneous loss and alteration of antigen receptor expression in mature $\mathrm{CD}^{+} \mathrm{T}$ cells. J Exp Med 1990; 171: 1981-1999.

3) Umeki S, Kyoizumi S, Kusunoki Y, et al. Flow cytometric measurements of somatic cell mutations in Thorotrast patients. Jpn J Cancer Res 1991; 82: $1349-1353$

4) Kyoizumi S, Umeki S, Akiyama $M$, et al. Frequency of mutant $T$ lymphocytes defective in the expression of the T-cell antigen receptor gene among radiationexposed people. Mutation Res $1992 ; 265$ : 173-180.

5) Akiyama M, Umeki S, Kusunoki $Y$, et al. Somaticcell mutations as a possible predictor of cancer risk. Health Physics 1995; 68: 643-649.

6) Till JE, McCulloch EA. A direct measurement of the radiation sensitivity of normal mouse bone marrow cells. Radiat Res $1961 ; 14: 213-222$.

7) Kohn HI, Kallman RF. The influence of strain on acute X-ray lethality in the mouse $\mathrm{I} . \mathrm{LD}_{50}$ and death rate studies. Radiat Res $1956 ; 5: 309-317$.

8) Grahn D, Hamilton KF. Genetic variation in the acute lethal response of four inbred mouse strains to whole body X-irradiation. Genetics $1957 ; 42: 189-$ 198.

9) Storer JB. On the relationship between genetic and somatic sensitivity to radiation damage in inbred mouse strains. Radiat Res 1967; 31:699-705.

10) Yuhas JM Storer JB. On mouse strain differences in radiation resistance: hematopoietic death and the endogenous colony-forming unit. Radiat Res 1969; 39 : 608-622.

11) Sado T, Kamisaku H, Kubo E. Strain difference in the radiosensitivity of immunocompetent cells and its 
influence on the residual host-vs-graft reaction in lethally irradiated mice grafted with semiallogeneic bone marrow. J Immunology 1985; 134 : 704-710.

12) Sado T, Kamisaku H, Ikarashi Y, Kudo E. Immediate and long-term effects of radiation on the immune system of specific-pathogen-free mice. Int $\mathbf{J}$ Radiat Biol 1988; 53: 177-187.

13) Hanson WR, Fry RJM, Sallese AR, Frischer H, Ahmad T, Ainsworth EJ. Comparison of intestine and bone marrow radiosensitivity of the BALB/C and the $\mathrm{C} 57 \mathrm{BL} / 6$ mouse strains and their $\mathrm{B} 6 \mathrm{CF}_{1}$ offspring. Radiat Res $1987 ; 110: 340-352$.

14) Julius MH, Simpson E, Herzenberg LA. A rapid method for the isolation of functional thymus/derived murine lymphocytes. Eur J Immunol 1973; 3: 645-649

15) Mori N, Okumoto $\mathbf{M}$, Morimoto $\mathrm{J}$, et al. Genetic analysis of susceptibility to radiation-induced apoptosis of thymocytes in mice. Int J Radiat Biol 1992; 62 : $153-159$.
16) Mori $N$, Okumoto $M$, Yonezawa $M$, Nishikawa $R$, Takamori $Y$, Esaki K. Factors related to resistance to hematopoietic death in mice. J Radiat Res 1994; $35: 1-10$.

17) Dohi $S$, Norimura $T$, Kunugita $N$, Tsuchiya $T$. Determination of in vivo and in vitro radiosensitivity of mouse splenic $\mathrm{T}$-lymphocytes using a $\mathrm{T}$-cell cloning technique. J Univ Occup Environm Health 1989; 11 : 13-22.

18) Kunugita $N$, Norimura $T$, Dohi $S$, Watanabe $T$, Tsuchiya T. Strain difference of radiosensitivity of lymphocyte in mice (in Japanese). Nihon Igaku Hosyasen Gakkai Seibutu Bukaisi 1990; 3: 99-100.

19) Mei N, Kunugita N, Nomoto S, Norimura T. Comparison of the frequency of $\mathrm{CD}^{-} 4^{+}$mutants and 6thioguanine resistance induced by $\mathrm{x}$-rays or ENU in cultured human T-lymphocytes. In: Radiation Research 1895-1995, Congress Proceedings (Abstracts). $1995: 153$. 